\title{
Economic Education and Character Well-being of Art Therapy students
}

\author{
Yulita Kurniawaty Asra ${ }^{1}$, Dian Cita Sari ${ }^{2, *}$, Vivik Shofiah ${ }^{3}$, Mukhlis ${ }^{4}, U_{m m i}$ Rasyidah $^{5}$ \\ ${ }^{1}$ UIN Sultan Syarif Kasim Riau, Indonesia \\ ${ }^{2}$ UIN Sultan Thaha Saifuddin Jambi, Indonesia \\ ${ }^{3}$ UIN Sultan Syarif Kasim Riau, Indonesia \\ ${ }^{4}$ UIN Sultan Thaha Saifuddin Jambi, Indonesia \\ ${ }^{5}$ Universitas Pasir Pengaraian, Indonesia \\ ${ }^{*}$ Corresponding author.Email:_diancita1@gmail.com
}

\begin{abstract}
This text explores the economic science of education and character well-being of art theraphy students. The analysis subjects were eighteen folks taken by purposive sampling methodology. This study uses a real experimental style wherever within the true experimental style there's a random sample choice method (randomization) of the cluster being treated (experimental cluster) or because the management group. the aim of true experimental analysis is: to research the likelihood of a causative relationship by applying to at least one or additional experimental teams, one or additional treatment conditions and examination the results with one or additional management teams that don't seem to be subject to treatment conditions. The results of the study found: SRT theraphy was effective in strengthening awareness of economic education from associate degree early age and also the formation of character welfare. many determinants were found, such as: intensity of treatment, environmental factors, cluster size and members additionally the $\}$ kind of reinforcement that also supported the success of giving a treatment.
\end{abstract}

Keywords: Economic, character, art therapy

\section{INTRODUCTION}

In order to comprehend the action of economic equality and succession of instructional goals, instructional activities are through three instructional channels, particularly formal, non-formal, and informal channels [1]. Formal education in formal establishments, like faculties. Non-formal education like courses, tutoring, and so on.

Education is predicted to supply changes that may develop a nation. Education in UUSPN No. twenty of 2003 in article one purpose one may be a aware and planned effort to make a learning atmosphere and learning method in order that it actively develops its potential forever within future, together with functioning for community and country. [2]

Character is identical with temperament or morals. Temperament may be a characteristic, characteristic, or characteristic of someone World Health Organization comes from formations received from the setting, like family in childhood and innate from birth. beside this understanding, there's a gaggle of individuals World Health Organization argue that the great and dangerous of human character is innate from birth. [3] The family setting is that the initial and foremost instructional setting for kids, as a result of it's during this family that kids initial receive education and steerage. [4] It's aforesaid to be primary as a result of most of the child's life is within the family. The family setting mutually of the crucial factors that influence a child's personal development will be any divided into 3 aspects, namely: (a) the family's status, (b) closeness of oldsters and youngsters, and (c) parenting/ means folks educate kid [5]. Whereas internal factors will be within sort of factors that support or hinder power of World Health Organization from intervals themselves closely associated with their temperament.

In the method of guiding, there must be mastery to strengthen behavior in order that it will be in accordance with expectations. Reinforcement is required in order that great potential that's already owned becomes consistent and is mirrored in behavior that. Institution reinforcement will amendment student behavior. Islamic characteristics possessed by Muslims that sourced from Qur'an and 
Hadith [7]. Character is typical-good values (knowing worth of goodness, willing to try smart, having a true smart life, and having an honest impact on environment) that imprinted in themselves and seen through consistent daily behaviour [8].

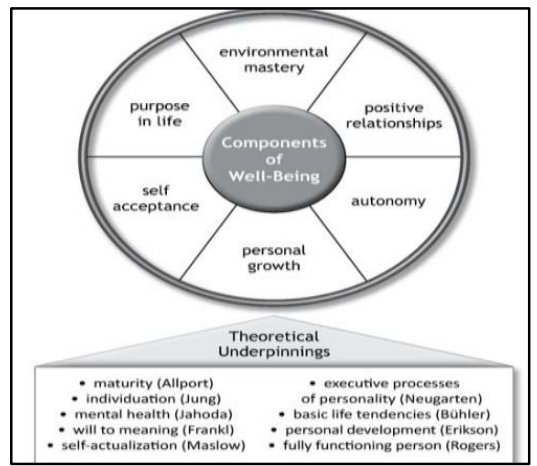

Figure 1. Element of well-being

(Source: Castelnau et all, 2017)

Character education has been introduced since decennary. Thomas Lickona is taken into account because bearer, particularly once he wrote a book entitled come back of Character Education and later his book, Educating for Character: however our college will Teach Respect and Responsibility. Character education contains 3 main components, particularly knowing the great (knowing the good), gaga the great (desiring the good), and doing great (doing the good) [9]. On the opposite hand, Herman Northrop Frye defines character education as, a national movement making faculties that foster accountable, moral, and caring youth by modeling and teaching smart character through a stress on universal values that we tend to all share. [10]

There are numerous sorts of art theraphy, however the foremost wide utilized in theraphy normally are visual arts, particularly painting and drawing [11]. Supported analysis conducted by Wallin and Duur, [12] It's celebrated that drawing activities will improve social and emotional learning skills in kids. Drawing also can create kids additional mature and on top of things and provides a sense of ability [13]. Strengthening character of Islam from associate degree early age suggests that taking part in getting ready the nation's generation of character, They are future generations of World Health Organization are expected ready to lead state and create a civilized country, uphold the noble values of state with smart morals and character and become a generation with high information and beautify themselves with religion and piousness [14]. Therefore, activities to strengthen Moslem character through art in a shot form kids behave supported Moslem character. The formation of character are higher if emerges from spiritual awareness. It's supported entrenched behavior in society [15].

Naumberg describes this methodology art theraphy by emotional the unconscious through spontaneous creative expression, because the root of the transfer of the connection between patient and expert on the impulse of intellection that refers to psychotherapy theory, treatment depends on developing relationships that ar taken by the patient through symbolic style, will be conjointly the ensuing image becomes a sort of communication between the patient and also the expert.[16]

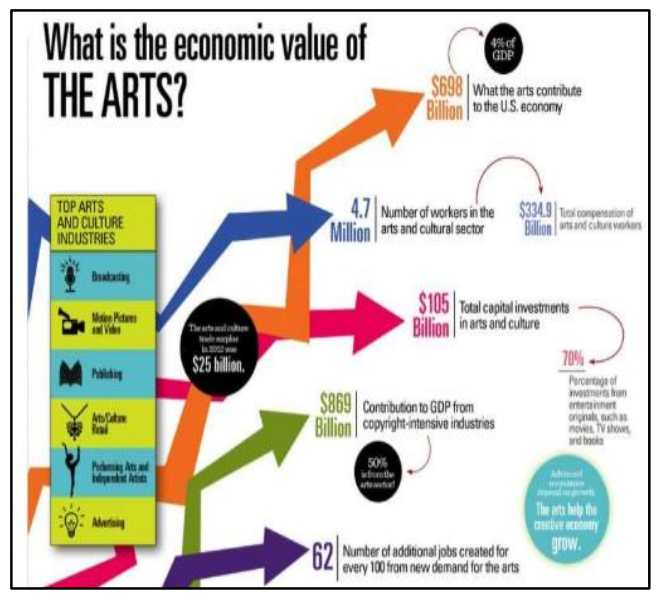

Figure 2 Future Goal of Art Therapy: EconomicEducation (Source: Serlin, 2007)

The same issue was expressed by Serlin (2007) that Art theraphy brings a psychotherapy perspective to use art as some way to make aware pictures and aware symbols. [17] Art theraphy may be a therapeutic method victimization personal awareness and alter happens once patients or purchasers move throughout the method of art materials and once people are ready to learn one thing regarding themselves from the method. [18]

Various theoretical approaches in Art theraphy itself embody psychotherapy, archetypes, object relations, humanistic, cognitive-behavioral, and biological process. Art theraphy itself will be used on kids, adults, teams and families to figure with emotions, resolve conflicts and improve well-being [19]. Although Namberg adopted Hill's theraphy, it's perception of each deciphering art theraphy [20]. Hill refers to art as theraphy, whereas Namberg expresses it as a sort victimization art in theraphy. Art theraphy develops in two parallel stages, primary is art as theraphy and art of psychotherapy. Art as theraphy presses it on healing with creative potential, whereas art therapy emphasizes importance powerful therapeutic relationship between the art expert, the shopper and also the design.

Art theraphy involves process and making pictures (from raw forms into symbolic expressions) and providing therapeutic relationships. From therapist-client relationship that is an exact exploration of photographs and objects created by topic, this enables expert to achieve robust understanding of himself and also the nature, difficulties and pressures old that successively will result in positive and lasting changes relationships and also the client's overall quality of life. [16]

Art theraphy many things ought about characteristics during this theraphy [17]. First, associated with non- 
verbal communication. This theraphy will facilitate purchasers World Health Organization cannot categorical issues verbally, the communication will be sent implicitly through a series of arts within the theraphy that's meted out. This type of communication is taken into account additional authentic than verbal language, though it's tons of diversity.

\section{METHODOLOGY}

This study uses a real experimental style wherever within the true experimental style there's a random sample choice method (randomization) of experimental cluster or because the management cluster. the aim of true experimental analysis is: to research the likelihood of a causative relationship by applying to at least one or additional experimental teams, one or additional conditions. Treatment and compare the results with one or additional management teams that don't seem to be subject to treatment conditions [21]. Shape utilized in this study was a irregular pretest-posttest management cluster style, during which there have been 2 teams of samples chosen every which way within pretest-posttest management cluster style, the experimental cluster and also management cluster got pretest. Then experimental cluster was given treatment, whereas management cluster wasn't given treatment. After that, posttest was conducted on the experimental cluster and also management cluster. Aggregation knowledge during this study victimization tests, interview sheets, and observations.

\section{RESULT AND DISCUSSION}

Subjects during this study amounted to eighteen folks whose determination was taken by purposive sampling supported bound criteria thought-about by the research worker. Meanwhile, to decide on between subjects which will be used as experimental teams and subjects for the management cluster, researchers use random assignment random assignment may be a style that gives constant chance or likelihood every analysis subject to be enclosed in each cluster. Eighteen folks that have consummated the necessities during this study then took a pretest to induce associate degree initial image of their information of sex. Additionally, Pre-test was conjointly conducted to categorise themes that will be used because the basis for random assignment to work out themes World Health Organization were within the experimental cluster and World Health Organization became management cluster.

Based on information obtained from the mensuration of information sex in adolescents with delicate slowness, the researchers classified themes supported 3 classes, particularly adolescents World Health Organization had high, medium and low information of sex. This categorization relies on the idea that the score of the topic within the cluster is associate degree estimate of the score of the topic during a unremarkably distributed population that aims to put people in separate teams little by little per a time supported measured attributes [22] antecedently raw scores regenerate into normal scores information will be compared with each other. The subsequent may be a categorization of subjects their Moslem character. The hypothesis during this study is that art theraphy is effective in strengthening Moslem character. Testing of the projected hypothesis is meted out victimization SPSS program. Analysis results hypothesis testing was cluster knowledge and individual knowledge.

Based on results of Mann Whitney take a look at on analysis knowledge on gender information time pretest, there was no important distinction between experimental cluster and also the management cluster ( $p=$ zero.931). These results indicate that the initial conditions between the management cluster and also the experimental cluster area unit equivalent or balanced. whereas the results of the Mann Whitney take a look at on analysis knowledge at time of posttest, which implies the analysis knowledge when intervention, specifically art theraphy, showed a major distinction between management cluster and also the experimental cluster ( $\mathrm{p}=$ zero.024). The results of the Wilcoxon t-test between the experimental cluster conjointly the management cluster at the time of the pretest also showed no important distinction $(\mathrm{p}=0.635)$. The analysis knowledge at the posttest for the experimental cluster showed the next average score (mean=24.67) compared to management cluster average $($ mean=19.22). This strengthens results of Wilcoxon ttest between experimental cluster and also management cluster at time of posttest that showed a major distinction $(p=0.012)$. Supported the info obtained on top, it may be over that hypothesis that states: art theraphy is effective in strengthening Moslem character is acceptable.

Based on results study, it had been found that mean score of experimental cluster at posttest was above mean score of management cluster. This distinction indicates a major distinction. This result's in line with the Mean U Whitney take a look at that states that there's a distinction between experimental cluster and management cluster in Moslem character $(p=0.024)$. This shows that results of art theraphy analysis have verified to be effective in Moslem character. Results of this effective art theraphy treatment will occur because:

a) Intensity of treatment. Art theraphy during this study was given for six conferences. One meeting is command for two hours. Therefore total treatment is twelve hours.

b) Environmental factors. One in every of foremost cogent surrounding in faculty environment. Causative faculty surrounding teaches regarding principles consistent with Moslem teachings even have a bearing on increasing therapeutic outcomes. The teacher's heat perspective Associate in nursing being an example for college kids additionally influences. Youngsters develop social skills through method of modeling surroundings and thru receiving rewards once doing one thing that's in accordance with stress of surroundings. 
c) Size and cluster members tiny cluster members area unit a lot of doubtless to realize effective results as a result of youngsters area unit easier to manage, direct and a lot of doubtless to tolerate different members.

d) Reinforcement provided. Positive reinforcement are a few things that once given can increase behavior, specifically giving rewards or praise, giving positive things within the type of praise, gifts and valuable things to the perpetrators of behavior that area unit thought of smart and need to be exaggerated once more in frequency. The reinforcing nature here are a few things that creates the scholars involved feel valued, happy, feel themselves eminent and different positive things. the shape of reinforcement within the type of praise, awards will create youngsters feel assured so that they area unit driven to try and do higher things within the future.

In a up to date perspective art theraphy is outlined as a type of theraphy that makes pictures or drama objects that play central role with psychotherapeutic relationship between art healer and also shopper. The Association of Art Therapists within the Great Britain, defines Art theraphy because the use of art materials for expressive style and reflection within the presence of a trained art healer. The goal of the professional person is to modify the shopper for modification and growth on a private level through the utilization of creative materials during a safe and accessory surroundings.

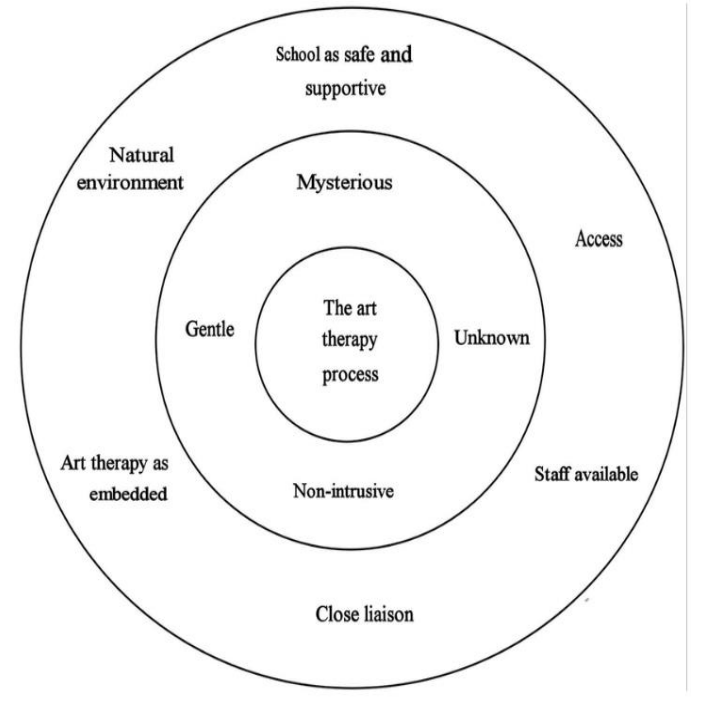

Figure 3 Art theraphy method (Source: www.arttherapy.org)

The Art theraphy Association defines art theraphy as: theraphy that uses art, in skilled relationships, by folks with health problem, trauma, challenges in life or by folks seeking personal development. Through making art and reflective on art merchandise and processes, folks will increase awareness of themselves et al., deal with symptoms of stress and traumatic experiences, improve psychological feature talents, and luxuriate in pleasure in art. Meanwhile, the Canadian Art theraphy Association and also the Australian National Art theraphy explicit that Art theraphy may be a type of psychotherapy that enables for emotional expression and healing through nonverbal means that. wherever youngsters area unit seen as in contrast to most adults, they typically cannot simply categorical themselves verbally. Today, the information began to develop words may be wont to see the intellect and prevent from emotions. Art theraphy itself permits purchasers to interrupt through complicated barriers to expressive style exploitation art materials. [22].

Art theraphy continues to be employed in varied Art theraphy activities. Art theraphy is simply too typically viewed as a ability or technique, instead of a definite therapeutic modality. this can be potential attributable to cluster members from different professionals United Nations agency have used art or pictures for diagnostic or therapeutic functions. These professions embody community and hospital based mostly psychiatrists, activity therapists, nurses, employees, and academics.

\section{CONCLUSION}

In conclusion, this study investigates the moderating economic effects have specific contexts on relationship between international Islamic education and economic strategy by statistically integrating empirical insights accumulated in a large body of literature. By examining economic strategy decisions at international entries, this paper provides evidence showing under what conditions the experiential learning is associated with economic s' economic strategy for entering a market. The empirical results largely support theoretical predictions that economic size of international Islamic education, and economic development. In turn, this paper posits that a international islamic education in strategy collaboration positively relates to its economic strategy at an international entry and that this relationship rests on the economic's experience-based capabilities. It is the economic's ability to deploy these capabilities and their applicability that condition this relationship. These theoretical and empirical contributions fill some of the critical gaps in extant literature for multiple moderators simultaneously and synthesizing diverse findings with a systematic study.

This rapid review has succeeded in identifying the economic in international Islamic education strategy collaboration, how economic integrate the international Islamic education used with strategy collaboration, and how economic facilitate strategy, in which these four things reflect a small part of the way economic facilitate international Islamic education strategy collaboration. The way economic facilitate internationalization Islamic education with strategy collaborate revealed in this study hints at several issues of improvement that might be considered by economic education stakeholders, policymakers, or educational authorities. 


\section{ACKNOWLEDGMENT}

The author teams are grateful to CEL KODELN, ICESEBE Comitee and Makasar State University (UNM).

\section{REFERENCES}

[1] Gabriels, R. L. 2003, Art Therapy with Children Who Have Autism and Their Families. In C. A. Malchiodi (Ed.), Handbook of Art Therapy (pp. 193-206). New York London: The Guilford Press A Division of Guilford Publications, Inc.

[2] Serlin, I. A, 2007, Why is art important for psychology? The Arts Therapies: Whole Person Integrative Approaches To Healthcare. Theory and Practice of Art Therapist.

[3] The British Association of Art Therapists., 2014, Art Therapy Information, 1-12. Retrieved from www.baat.org

[4] Vick, R. M, 2003, BriefHistory of Art Therapy. In C. A. Malchiodi (Ed.), Handbook of Art Therapy. New York London: The Guilford Press A Division of Guilford Publications, Inc.

[5] Curry, N. a., \& Kasser, T, 2005, Can Coloring Mandalas Reduce Anxiety? Journal of the American Art Therapy Association, 22(2), 81-85. https://doi.org/10.1080/07421656.2005.10129441

[6] Do, H., Education, A., \& Differ, A. T, 2011, Information Resource About Art Therapy and Schools (310).

[7] Castelnau, P., Albert, G., Chabbi, C., Gilles, C., Deseille-Turlotte, G., Schweitzer, E., \& Thibault, L, 2017, Self-esteem reinforcement strategies in well being: Comparison between hypnosis and arttherapy. European Journal of Paediatric Neurology, 21. https://doi.org/10.1016/J.EJPN.2017.04.1290

[8] Gliga, F. 2011, Teaching by Art Therapy. Procedia Social and Behavioral Sciences, 15, 3042-3045. https://doi.org/10.1016/j.sbspro.2011.04.241

[9] Kramer, E. 1980, Art Therapy and art education: Overlapping functions. Art Therapy and Art Education, 33(4), 16-17.

[10] Riley, S. 2003, Art Therapy with Couples. In C. A. Malchiodi (Ed.), Handbook of Art Therapy (pp. 387-398). New York London: The Guilford Press A Division of Guilford Publications, Inc.

[11] Morris, F, 2013, Brief Cognitive Behavioral Art Therapy For Anxiety Disorders. The Florida State University College Of Visual Arts, Theatre, And Dance. The Florida State University College Of Visual Arts, Theatre, And Dance.

[12] Wallace, K. O. 2015, Art Therapy and autism. In Transgressions: Cultural Studies and Education book series (pp. 37-42). Rotterdam: SensePublishers. https://doi.org/10.1007/978-946300-001-7_5
[13] Rappaport, L., Ph, D., \& Gendlin, E. T, 2008, Focusing oriented art theraphy, 139-155.

[14] Regev, D., Green-Orlovich, A., \& Snir, S. 2015, Art Therapy in schools. The therapist ${ }^{\text {ee }}$ s perspective. Arts therapy, 47-55. doi.org/10.1016/j.aip.2015.07.004

[15] Nguyen, M. 2016, Art Therapy - A Review of Methodology, (January 2015).

[16] Naumberg, M. 2004, What is Art Therapy? In Dynamically Oriented Art Therapy (pp. 1-17).

[17] Haque, S., \& Haque, M. (2015). Art Therapy and autism. Asian Journal of Pharmaceutical and Clinical Research, 8(6), 202-203. https://doi.org/10.1007/978-1-4614-64358 102047-1

[18] Safran, D. S. 2003, An Art Therapy Approach to Attention-Deficit/Hyperactivity Disorder. In C. A. Malchiodi (Ed.), Handbook of Art Therapy (pp. 181-192). New York London

[19] Van Lith, T., Stallings, J. W., \& Harris, C. E. 2017, Discovering good practice for Art Therapy with children who have Autism Spectrum Disorder: The results of a small scale survey. Arts in Psychotherapy, 54, 78-84. https://doi.org/10.1016/j.aip.2017.01.002

[20] Schweizer, C., Knorth, E. J., \& Spreen, M. 2014, Art Therapy with children with Autism Spectrum Disorders: A review of clinical case descriptions on "what works." Arts in Psychotherapy, 41(5), 577593. https://doi.org/10.1016/j.aip.2014.10.009

[21] Eaton, L. G., Doherty, K. L., \& Widrick, R. M., 2007, A review of research and methods used to establish Art Therapy as an effective treatment method for traumatized children. The Arts in Psychotherapy, 34(3), 256-262. https://doi.org/10.1016/j.aip.2007.03.001

[22] American Art Therapy Association, 2013, What is Art Therapy? American Art Therapy Association. Retrieved from http://www.arttherapy.org 